\title{
GCG, PROFITABILITAS, DAN NILAI PERUSAHAAN ASURANSI: EFEK MODERASI UKURAN PERUSAHAAN
}

\author{
Lucky Pramestie ${ }^{1}$ \\ Apriani Dorkas Rambu Atahau ${ }^{2}$ \\ ${ }^{1,2}$ Fakultas Ekonomi dan Bisnis Universitas Kristen Satya Wacana (UKSW), Jawa \\ Tengah, Indonesia \\ email: luckypramestie13@gmail.com
}

\begin{abstract}
ABSTRAK
Penelitian ini bertujuan menganalisis pengaruh Good Corporate Governance (GCG) dan profitabilitas terhadap nilai perusahaan dengan ukuran perusahaan sebagai variabel moderasi. Penelitian ini menggunakan laporan keuangan perusahaan asuransi periode 2017-2019. Sample pada penelitian ini sebanyak 12 perusahaan asuransi yang diperoleh menggunakan teknik purposive sampling. Teknik analisis penelitian menggunakan regresi data panel. Hasil penelitian ini menunjukkan bahwa GCG dan profitabilitas tidak berpengaruh terhadap nilai perusahaan dengan ukuran perusahaan sebagai variabel moderasinya.

Kata kunci: GCG; profitabilitas; nilai perusahaan; ukuran perusahaan.
\end{abstract}

\begin{abstract}
This research aims to analyze the influence of Good Corporate Governance (GCG) and profitability on firm value as a moderating variable. This research uses reports of insurance financial companies for the period 2017-2019. The sample in this research were 12 insurance companies obtained using purposive sampling technique. The research analysis technique used panel data regression. The result of this research indicate that $G C G$ and profitability have no effect firm value with firm size as the moderating.

Keywords: GCG; profitability; firm value; firm size.
\end{abstract}




\section{PENDAHULUAN}

Kondisi ekonomi Indonesia mengalami pasang surut beberapa tahun ini. Setelah mencatatkan pertumbuhan yang stabil pada kisaran 5\% maka situasi pandemi mengakibatkan penurunan pertumbuhan ekonomi secara drastis sehingga mencapai -2,07\% di tahun 2020 (BPS, 2021). Kondisi ini menunjukkan pentingnya perusahaan-perusahaan Indonesia untuk berbenah diri agar dapat bersaing di kondisi kondisi ekonomi yang tidak menentu tersebut agar dapat mempertahankan eksistensi perusahaan. Di kondisi seperti ini, perusahaan tidak hanya berorientasi untuk memaksimalkan laba namun perusahaan juga perlu memperhatikan kinerjanya agar dapat mempertahankan nilai perusahaannya. Berbagai strategi baru dan perbaikan sistem perusahaan sangat diperlukan dalam hal ini.

Perbaikan yang dilakukan perusahaan mencakup implementasi good corporate governance (GCG) yang baik agar nilai perusahaan dapat dipertahankan dalam situasi seperti ini. Good corporate governance yang baik diharapkan berkontribusi dalam pencapian kinerja yang lebih (Muchtar \& Darari, 2013). Melalui kinerja yang meningkat tersebut maka investor diharapkan tertarik menginvestasikan modalnya ke perusahaan, kemudian menggunakan harga saham sebagai indikator pengukuran terhadap nilai perusahaan. Nilai perusahaan yang tinggi diharapkan memampu mencapai salah satu tujuan perusahaan yaitu menjamin kesejahteraan pemegang saham (Thaharah \& Asyik, 2016). Kebutuhan GCG akan timbul berkaitan dengan agency theory.

Melalui penerapan GCG maka terjadi pengawasan yang lebih baik terhadap keputusan manajemen agar tidak terjadi penyimpangan. Hal ini disebabkan karena pihak manajemen yang langsung terlibat di perusahaan sehingga memiliki informasi yang lebih memadai dibandingkan pemilik. Dalam hal ini dimungkinkan terjadinya asimetri informasi antara pihak manajemen dengan pemilik perusahaan. Informasi laporan keuangan diperoleh dari pihak manajemen sehingga ada keterbatasan karena pemilik tidak terlibat dalam operasi perusahaan sehari-hari.

Untuk mengevaluasi kinerja perusahaan dilakukan pengukuran kinerja. Pengukuran kinerja keuangan dapat mempengaruhi dalam perilaku pengambilan keputusan, karena kinerja keuangan digunakan sebagai masukan untuk memperbaiki kinerja perusahaan termasuk untuk menyusun sistem imbalan. Selain itu, menurut Le Thi Kim \& Le Thanh (2020) kinerja keuangan yang tinggi selalu menarik perhatian utama dari setiap manajer, karena digunakan sebagai alat ukur perkembangan perusahaan saat ini dan potensi pertumbuhan dimasa depan. Rasio profitabilitas dapat melihat seberapa efektif dan efisiennya perusahaan dalam mengelola asset atau sumber daya untuk memaksimalkan nilai perusahaan (Rahardjo \& Murdani, 2016). Profitabilitas menjadi hal penting dalam menunjang kelangsungan hidup perusahaan, karena investor akan melihat tingkat profitabilitas perusahaan untuk menentukan kebijakan dan mengambil keputusan penanaman modal atau investasi.

Perusahaan asuransi merupakan lembaga keuangan nonbank yang mempunyai peranan dalam bidang layanan jasa dalam mengatasi resiko yang akan terjadi di masa yang akan datang. Penelitian yang dilakukan oleh Amanda \& Rambu Atahau (2020) menyatakan bahwa perusahaan asuransi memiliki resiko kebangkrutan yang tinggi apabila perusahaan tidak menjalankan tugas dan 
tanggung jawab dengan baik dan benar. Di Indonesia terdapat kasus yang melibatkan perusahaan asuransi, yaitu PT Asuransi Jiwasraya yang merugi hingga 27,7 triliun sehingga gagal bayar klaim nasabah (Kompas, 2020). Kerugian Jiwasraya yang sangat besar tersebut terjadi karena kejahatan korporasi berupa buruknya tata kelola, korupsi, dan sejumlah kecurangan terkait pengelolaan investasi. Kasus kedua menimpa PT Asuransi Sosial Angkatan Bersenjata Republik Indonesia (ASABRI). Permasalahannya adalah PT Asuransi Sosial Angkatan Bersenjata Republik Indonesia (ASABRI) diduga merugi hingga 10 triliun (Kompas, 2020). Kasus ketiga adalah menimpa Asuransi Jiwa Bersama Bumiputera, dimana permasalahannya adalah masalah keuangan membelit Asuransi Jiwa Bersama Bumiputera (Kompas, 2020).

Kasus-kasus tersebut terjadi setelah Otorotitas Jasa Keuangan mengeluarkan peraturan No. 73/POJK.05/2016 pasal 1 angka 25 menyebutkan bahwa tata kelola perusahaan yang baik, adalah struktur dan proses yang digunakan dan diterapkan organ perusahaan perasuransian untuk meningkatkan pencapaian sasaran hasil usaha dan mengoptimalkan nilai perusahaan perasuransian bagi seluruh pemangku kepentingan khususnya pemegang polis, tertanggung, peserta, dan/atau pihak yang berhak memperoleh manfaat, secara akuntabel dan berlandaskan peraturan perundang-undangan serta nilai-nilai etika (OJK RI, 2016). Peraturan yang dietapkan oleh OJK bertujuan untuk meminimalisir terjadinya dampak buruk yang disebabkan oleh kesalahan pengelolaan perusahaan. Sejauh mana implementasi peraturan pada industri ini menarik diteliti karena setelah sekian lama peraturan tersebut dikeluarkan belum dapat memenuhi tujuan dari OJK dan masih terjadi kasus-kasus berkenaan dengan tata kelola perusahaan yang buruk. Oleh karena itu, hal ini perlu untuk dikaji ulang dan dievaluasi untuk menemukan solusi bagi tata kelola perusahaan agar lebih baik.

Penelitian tentang pengaruh Good Corporate Governance (GCG) dan nilai perusahaan dilakukan oleh Thaharah \& Asyik (2016) dan Meindarto \& Lukiastuti (2016) mendapatkan hasil bahwa GCG tidak berpengaruh terhadap nilai perusahaan. Penelitian yang dilakukan Oktariyani et al. (2017) mendapatkan hasil yang berbeda yaitu GCG berpengaruh terhadap nilai perusahaan. Wardoyo \& Veronica (2013) dan Thaharah \& Asyik (2016) menyatakan bahwa profitabilitas berpengaruh terhadap nilai perusahaan, sedangkan Pramana \& Mustanda (2016) mendapatkan hasil yang berbeda bahwa profitabilitas tidak berpengaruh terhadap nilai perusahaan. Kemudian, penelitian yang dilakukan Soedaryono \& Riduifana (2013) menemukan hasil bahwa GCG dan Profitabilitas berpengaruh terhadap nilai perusahaan.

Penelitian Badruddien et al. (2017) menyatakan bahwa ukuran perusahaan dapat digambarkan dengan melihat besar kecilnya total aktiva atau total penjualan bersih. Ukuran perusahaan yang semakin besar maka semakin mudah perusahaan memperoleh sumber pendanan, hal ini menunjukkan jika perusahaan mengalami perkembangan sehingga investor akan merespon positif dan nilai perusahaan akan meningkat. Dalam penelitian ini ukuran perusahaan diukur menggunakan total aktiva perusahaan. Menurut Firmansyah (2017) para investor lebih tertarik berinvestasi di perusahaan yang ukurannya lebih besar, karena dianggap lebih mampu menghadapi tekanan ekonomi dan menghasilkan profitabilitas yang tinggi. 
Hal tersebut dapat memperkuat tata kelola perusahaan sehingga meningkatkan nilai perusahaan. Efisiensi perusahaan dapat digambarkan dari umur perusahaan, dimana perusahaan dengan umur yang lebih lama dianggap lebih efisien karena karena efek learning curve (Ang, Cole, \& Lin, 2000). Perusahaan yang sudah lama berdiri cenderung memiliki banyak pengalaman. Oleh karena pengalaman yang dimilikinya, perusahaan yang tua cenderung memahami industri yang dijalaninya.

Penelitian Thaharah \& Asyik (2016) berfokus pada pengaruh mekanisme corporate governance dan kinerja keuangan terhadap nilai perusahaan. Penelitian ini menambahkan dua variabel yaitu ukuran perusahaan dan usia perusahaan. Variabel ukuran perusahaan ditambahkan sebagai variabel moderasi untuk menguji efek moderasi ukuran perusahaan terhadap relasi good corporate governance dan profitabilitas terhadap nilai perusahaan. Dari pemaparan di atas, maka penelitian ini bertujuan untuk mengetahui pengaruh good corporate governance dan profitabilitas terhadap nilai perusahaan dengan ukuran perusahaan sebagai variabel moderasi.

Persoalan penelitian yang akan diuji dalam penelitian ini adalah bagaimana pengaruh good corporate governance dan profitabilitas terhadap nilai perusahaan asuransi? Apakah ukuran perusahaan memoderasi pengaruh GCG dan profitabilitas terhadap nilai perusahaan? Adapun manfaat penelitian ini yaitu sebagai bahan evaluasi dan masukan bagi perusahaan asuransi pada khususnya dalam pengambilan keputusan mengenai penerapan good corporate governance dan profitabilitas untuk mempengaruhi nilai perusahaan. Meskipun fokus pada perusahaan asuransi, namun penelitian ini juga dapat digunakan bagi perusahaan lainnya baik bagi skala besar maupun kecil. Bagi investor bermanfaat sebagai pertimbangan untuk melakukan investasi dengan memperhatikan variabel yang mempengaruhi nilai perusahaan. Selain itu, penelitian ini diharapkan mampu berkontribusi bagi studi empiris dalam ilmu ekonomi manajemen khususnya pada penerapan ekonomi manajemen perusahaan.

Teori keagenan menurut Fayezi et al. (2012) merupakan sebuah hubungan pihak pertama (agen) yang bertindak sebagai perwakilan untuk kepentingan pihak kedua (principal). Teori keagenan menggambarkan relasi antara manajemen (agent) dengan pemegang saham (principal). Kebutuhan operasional perusahaan disediakan oleh principal dalam bentuk dana dan sumber daya lainnya dan agen berkewajiban dalam mengatur perusahaan (Wahyudin \& Solikhah, 2017). Konflik antara agent dan principal terjadi karena tindakan agen terkadang berbeda dengan maksud principal. Hal ini semakin diperkuat dengan posisi agen yang memiliki informasi internal lebih banyak dibandingkan prinsipal karena agen merupakan pelaksana operasional perusahaan. Agen diberikan kekuasaan dari prinsipal untuk mengelola perusahaan. GCG muncul akibat masalah keagenan bahwa ada perilaku yang menghasilkan keuntungan pribadi terutama dari agen dengan mempengaruhi pihak principal, sehingga penerapan sistem GCG diperlukan untuk mengawasi dan membimbing manajer dalam berinvestasi dan mengelola sumber daya perusahaan (Suhadak et al., 2019).

Good corporate governance merupakan suatu sistem yang berdasarkan pada aturan kerja, prosedur dan hubungan yang jelas antara para pelaku dalam suatu perusahaan ketika menjalankan peran dan tugasnya. Good corporate governance 
mempunyai lima prinsip yaitu transparency (transparansi) keterbukaan dalam mengemukakan informasi yang material dan relevan serta keterbukaan dalam proses pengambilan keputusan; accountability (akuntabilitas) kejelasan fungsi dan pelaksanaa pertanggung jawaban sehingga pengelolaannya berjalan efektif; responsibility (pertanggung jawaban) kepatuhan pengelolaan pada peraturan dan prinsip-prinsip yang berlaku; independency (kemandirian) pihak manajemen mengelola perusahaan sesuai peraturan yang berlaku; fairness (kewajaran) memberikan hak-hak stakeholders sesuai perjanjian dan peraturan yang berlaku (Noviani et al., 2019). Pada prinsip kerja perusahaan, perusahaan dipastikan menerapkan kelima prinsip dasar good corporate governance. Pada penelitian ini good corporate governance diukur menggunakan kepemilikan institusional dan komite audit. Alasan digunakannya variabel kepemilikan institusional sebagai salah satu variabel dalam penelitian ini karena pada perusahaan asuransi kepemilikan institusional dapat mengawasi manajemen dan berdampak baik pada laporan keuangan perusahaan. Pemilihan komite audit karena semakin baik komite audit di perusahaan semakin baik laporan keuangan yang nantinya dapat mempengaruhi nilai suatu perusahaan sehingga dapat menarik minat investor.

Meindarto \& Lukiastuti (2016) menyatakan bahwa kepemilikan institusional adalah saham yang dimiliki oleh institusi atau lembaga, seperti perusahaan asuransi, perusahaan investasi, bank dan kepemilikan institusi lainnya. Kepemilikan institusional mempunyai peran penting yaitu mengawasi perusahaan sehingga mendorong tingkat pengawasan yang dapat menjamin kemakmuran pemegang saham. Kepemilikan institusional berperan penting dalam mengurangi biaya keagenan. Selain mengurangi masalah agensi, peningkatan kinerja menjadi hasil yang masuk akal karena kepemilikan institusional memiliki kekuatan yang luar biasa untuk secara langsung mempengaruhi tindakan manajemen dan strategi perusahaan melalui suara/pendapat mereka yang dianggap terpenting (Ozdemir, 2020).

Menurut Saputra et al. (2018) dalam mewujudkan GCG suatu instansi, organisasi, maupun perusahaan diharuskan memiliki akuntabilitas dan transparansi. Komite audit wajib dimiliki oleh perusahaan yang sudah go public agar penyelenggaraan pengelolaan perusahaan yang baik karena berperan penting dalam kualitas laporan keuangan, hal tersebut diwajibkan oleh Bursa Efek Indonesia (BEI) dan Badan Pengawas Pasar Modal (BAPEPAM). Nilai perusahaan dapat meningkat karena kualitas laporan keuangan baik, dimana investor mendapatkan informasi di laporan keuangan. (Meindarto \& Lukiastuti, 2016).

Profitabilitas adalah kemampuan perusahaan untuk menghasilkan profit atau laba selama satu periode. Semakin baik sistem yang dijalankan suatu perusahaan dalam kegiatan operasionalnya akan meningkatkan profitabilitas perusahaan. Tingginya profit perusahaan menggambarkan manajemen dan pengelolaan perusahaan yang baik (Oktariyani et al., 2017). Rasio profitabilitas terdiri dari return on equity (ROE), gross profit margin, operating profit margin, dan return on assets (ROA). Dalam penelitian ini rasio profitabilitas diukur menggunakan return on assets (ROA). ROA dapat digunakan untuk mengukur perusahaan dalam menghasilkan laba bersih berdasarkan tingkat asset, sehingga semakin tinggi ROA maka semakin baik efisensi dan efektivitas pengelolaan asset perusahaan. 
Nilai perusahaan mencerminkan tingkat keberhasilan perusahaan yang terkait dengan harga saham. Nilai perusahaan dapat didefinisikan sebagai nilai pasar karena nilai perusahaan dapat memberikan kemakmuran pemegang saham secara maksimum apabila harga saham perusahaan meningkat. Thaharah \& Asyik (2016) menyatakan bahwa meningkatnya nilai perusahaan karena harga saham yang tinggi mengakibatkan tingkat pengembalian investor yang tinggi. Baik buruknya pengelolaan manajemen akan berpengaruh terhadap nilai perusahaan, sehingga dapat dikatakan bahwa pengelolaan perusahaan mencerminkan nilai perusahaan. Untuk mengukur nilai perusahaan dalam penelitian ini menggunakan rasio Tobins' $Q$, dimana semakin tinggi rasio maka semakin baik nilai suatu perusahaan.

Ukuran diartikan sebagai perbandingan besar kecilnya suatu objek. Besar kecilnya suatu perusahaan dapat diukur dengan total aktiva yang dimiliki perusahaan. Perusahaan dengan total aktiva yang besar, operasionalnya lebih stabil dan dapat menghasilakan laba sehingga prospek perusahaan ke depan lebih baik. Perusahaan yang memiliki total aktiva besar memiliki sumber pendanaan yang kuat karena kemudahaan aksebilitas ke pasar modal dan perusahaan sudah mencapai tahap maturity. Perusahaan dengan total aktiva yang lebih besar memiliki tingkat pengembalian investasi yang semakin tinggi sehingga nilai perusahaan semakin tinggi.

Dalam penelitian Suhadak et al. (2019) usia perusahaan didefinisikan sejak perusahaan didirikan sampai perusahaan masih beroperasi. Investor dapat menilai suatu perusahaan apakah mampu beroperasi dan bersaing dalam bisnis dengan melihat usia perusahaan, (Sembiring, 2012). Usia perusahaan juga mempengaruhi efesiensi perusahaan dalam melaksanakan kegiatan operasionalnya (Ang et al., 2000). Semakin lama usia perusahaan menandakan adanya kecenderungan bahwa perusahaan memiliki reputasi yang baik dan mampu bertahan dalam persaingan. Penelitian yang dilakukan oleh Hadya \& Fernandes (2020) menyatakan bahwa semakin tua usia perusahaan, maka cenderung memiliki pengalaman lebih banyak dan mampu dalam pengelolaan cash flow perusahaan dengan baik.

Kepemilikan/investor institusional dapat berperan dalam memonitor agen (manajer) perusahaan. Kepemilikan institusional meningkatkan kualitas tata kelola perusahaan yang berperan penting dalam efisiensi pasar modal serta mengkoreksi harga saham dengan informasi yang tepat, sehingga mengurangi volatilitas pengembalian saham (Daryaei \& Fattahi, 2020). Investor institusional memiliki informasi dan keahlian tentang kinerja perusahaan yang berdampak pada nilai perusahaan (Ellili, 2011). Kemampuan institusional dalam mengawasi manajer dengan jumlah saham atau hak suara yang dimiliki dapat berpengaruh terhadap nilai perusahaan. Muryati \& Suardikha (2014) berpendapat bahwa laporan keuangan perusahaan yang sesuai dengan keadaan sebenarnya akan memberikan reaksi positif investor dalam menilai perusahaan. Hal tersebut terjadi karena tingginya kepemilikan institusional di perusahaan. Nilai perusahaan dapat meningkat ketika tingkat pengawasan institusi tinggi, sehingga biaya keagenan turun yang artinya kepemilikan institusional berpengaruh positif terhadap nilai perusahaan hal ini sejalan dengan penelitian Perdana \& Rahaja (2014) dan Muryati \& Suardikha (2014). Hipotesis satu diajukan sebagai berikut: 
$\mathrm{H}_{1}$ : Kepemilikan institusional berpengaruh positif dan signifikan terhadap nilai perusahaan.

Komite audit memiliki peran yang penting dalam penyusunan laporan keuangan. Tindakan kecurangan keuangan (fraud) sebuah organisasi/perusahaan masih sering terdengar hingga saat ini. Komite audit pada prinsipnya berfungsi untuk mengoptimalkan pengawasan dan mengurangi kemungkinan terjadinya asymmetry information serta tindakan kecurangan keuangan (fraud) yang dapat mempengaruhi turunnya nilai perusahaan (Permata, et al., 2018). Kualitas laporan keuangan akan mempermudah investor dalam membaca informasi mengenai laporan keuangan perusahaan. laporan keuangan yang baik membuat nilai perusahaan akan meningkat (Susanti, 2010). Kewajiban komite audit dapat meningkatkan nilai perusahaan, karena kualitas laporan keuangan perusahaan yang dibuat oleh komite audit akan digunakan pihak internal dan eksternal perusahaan (Purbopangestu \& Subowo, 2014). Penelitian Siallagan \& Machfoedz (2006) menemukan pengaruh positif antara komite audit terhadap nilai perusahaan. Hasil pengaruh positif menandakan bahwa semakin baik komite audit sebuah perusahaan semakin tinggi pula nilai perusahaan, sehingga hipotesis dua diajukan sebagai berikut:

$\mathrm{H}_{2}$ : Komite audit berpengaruh positif dan signifikan terhadap nilai perusahaan.

Semakin tinggi profitabilitas, maka laba yang tersedia untuk dibagikan kepada pemegang saham juga menjadi lebih besar. Hal ini akan memberikan sinyal ke publik bahwa perusahaan relatif tidak mudah mengalami kebangkrutan atau financial distress, sehingga nilai perusahaan akan meningkat. Dalam penelitian ini, profitabilitas diukur dengan rasio Return on Asset (ROA). Perusahaan yang memiliki ROA tinggi menandakan bahwa perusahaan dikelola secara efektif, sehingga menghasilkan pendapatan secara optimal dengan memanfaatkan total aset mereka (Subramaniam \& Wasiuzzaman, 2019). Peningkatan ROA memperlihatkan potensi perusahaan ke investor sehingga manajemen lebih mudah untuk menarik modhal inial dalam bentuk saham. Ketika permintaan saham naik, maka harga saham naik (dengan asumsi ceteris paribus). Penelitian Chen \& Chen (2011) membuktikan bahwa profitabilitas (ROA) berpengaruh positif terhadap nilai perusahaan. Hipotesis tiga diajukan sebagai berikut:

$\mathrm{H}_{3}$ : Profitabilitas berpengaruh positif dan signifikan terhadap nilai perusahaan.

Ukuran perusahaan merupakan salah satu faktor yang dapat mempengaruhi manajemen dalam perataan laba. Ukuran perusahaan adalah ukuran besar kecilnya perusahaan yang dapat ditunjukkan salah satunya dengan total aktiva. Perusahaan kecil sedang dalam tahap pertumbuhan dalam siklus hidup mereka sehingga catatan pendapatan yang dilaporkan cenderung kurang untuk bisa dilacak (Shu \& Chiang, 2014). Ukuran perusahaan yang semakin besar maka kinerja manajemen semakin tinggi sehingga perlunya pengawasan terhadap manajemen. Dengan adanya kepemilikan institusional maka akan meningkatkan pengawasan terhadap manajemen, sehingga akan menjamin kemakmuran pemegang saham. Ketika pemegang saham terjamin kemakmurannya maka citra perusahaan baik. Hal tersebut mengakibatkan nilai perusahaan akan meningkat.

Kepemilikan istitusional akan meningkatkan pengawasan perusahaan sehingga mampu mengurangi biaya keagenan di perusahaan. Biaya keagenan yang 
berkurang akan meningkatkan nilai perusahaan. Perusahaan yang berukuran besar mempunyai prosedur pengawasan yang bersifat formal dan terdokumentasi. Pada perusahaan yang mempunyai ukuran besar, pengawasan oleh pemilik institusi lebih efektif sehingga akan menjamin kemakmuran pemegang saham. Ketika pemegang saham terjamin kemakmurannya maka citra perusahaan baik. Hal ini dapat menunjukkan pengaruh positif kepemilikan istitusi terhadap nilai perusahaan akan diperkuat oleh ukuran perusahaan. Hipotesis empat diajukan berikut ini:

$\mathrm{H}_{4}$ : Ukuran perusahaan memperkuat pengaruh positif antara kepemilikan institusional terhadap nilai perusahaan.

Perusahaan dengan ukuran besar memiliki asset yang besar. Ukuran perusahaan yang besar menandakan bahwa perusahaan memiliki struktur organisasi yang besar pula. Hal ini menunjukkan perusahaan mengalami perkembangan dari berbagai aspek, sehingga mendorong berbagai pandangan tentang pilihan kebijakan perusahaan, keberagaman pemikiran dan perilaku serta adanya kemungkinan terjadinya masalah pelaporan keuangan (Pacini, et.al., 2008). Komite audit menjadi penting untuk diterapkan dalam sebuah perusahaan, karena penerapan komite audit akan menghasilkan kualitas laporan keuangan. Perusahaan yang memberikan transparansi laporannya maka investor akan merespon positif. Semakin tinggi transparansi perusahaan, maka semakin tinggi pula nilai perusahaan yang ditunjukkan dengan harga saham Hansen \& Huniarti (2014) .

Komite audit mempunyai peran penting dalam kualitas laporan keuangan. Dengan demikian kualitas laporan keuangan yang baik akan meningkatkan nilai perusahaan. Pada perusahaan yang berukuran besar mempunyai asset yang besar, sehingga kualitas laporan keuangan dibutuhkan agar nilai perusahaan meningkat. Perusahaan yang memberikan transparansi laporan keuangan maka investor akan merespon positif. Ketika semakin tinggi transparansi perusahaan, maka semakin tinggi pula nilai perusahaan yang ditunjukkan dengan harga saham Hansen \& Huniarti (2014). Hal ini dapat menujukkan pengaruh positif komite audit terhadap nilai perusahaan yang diperkuat oleh ukuran perusahaan. Hipotesis lima diajukan sebagai berikut:

$\mathrm{H}_{5}$ : Ukuran perusahaan memperkuat pengaruh positif antara komite audit terhadap nilai perusahaan.

Meningkatnya laba perusahaan memberikan peluang bagi perusahaan untuk melakukan ekspansi atau memperluas dan memperbesar perusahaan. Perusahaan yang memiliki ukuran besar berpengaruh terhadap profitabilitas dan nilai perusahaan. Ukuran perusahaan yang semakin besar maka lebih relative stabil dan dapat menghasilkan profit. Profitabilitas menjadi sebuah indikator untuk mengukur kinerja manajemen (Noviani et al., 2019) dan apabila profitabilitas perusahaan meningkat maka perusahaan tersebut dapat menjamin kesejahteraan para pemegang saham dan kelangsungan hidup perusahaan. Para pemegang saham yang merasakan kesejahteraan ketika mereka menanamkan modal di sebuah perusahaan, akan memberikan feedback yang baik terhadap perusahaan tersebut, sehingga mengakibatkan nilai perusahaan dapat meningkat. Penelitian Hansen \& Huniarti (2014) menjelaskan bahwa semakin besar ukuran perusahaan maka berpengaruh terhadap profitabilitas dan nilai perusahaan. Meningkatnya profit akan meningkatkan nilai perusahaan terutama pada perusahaan skala besar. Dengan 
demikian ukuran perusahaan memperkuat pengaruh positif profitabilitas terhadap nilai perusahaan. Hipotesis enam diajukan sebagai berikut:

$\mathrm{H}_{6}$ : Ukuran perusahaan memperkuat pengaruh positif antara profitabilitas terhadap nilai perusahaan.

\section{METODE PENELETIAN}

Populasi pada penelitian ini adalah seluruh perusahaan asuransi yang terdaftar di BEI dari tahun 2017-2019. Sample pada penelitian ini diperoleh dengan metode purposive sampling. Kriteria dalam pemilihan sample sebagai berikut:

Tabel 1.

Penentuan Sample Penelitian

\begin{tabular}{lll}
\hline No & Kriteria & $\begin{array}{l}\text { Jumlah } \\
\text { Perusahaan }\end{array}$ \\
\hline 1 & Jumlah perusahaan yang terdaftar di BEI tahun 2017-2019 & 17 \\
2 & Perusahaan yang tidak memiliki kelengkapan data selama tahun $2017-$ & $(5)$ \\
2019 & 12 \\
Jumlah sampel akhir & 3 \\
Jumlah pengamatan (tahun) & 36 \\
Jumlah pengamatan &
\end{tabular}

Sumber : Jumlah perusahaan yang terdaftar di BEI tahun 2017-2019

Jenis data penelitian ini adalah data panel, yaitu gabungan antara cross section dan time series. Data sekunder pada laporan keuangan digunakan di penelitian ini, memuat data-data variabel kepemilikan institusional, komite audit, profitabilitas, nilai perusahaan, ukuran perusahaan, dan usia perusahaan. Periode penelitian mencakup 3 tahun yaitu dari tahun 2017 sampai dengan 2019. Perolehan data dilakukan dengan mengakses situs resmi Bursa Efek Indonesia (BEI) www.idx.co.id.

Rasio yang digunakan pada penelitian ini untuk mengetaui nilai GCG, profitabilitas, nilai perusahaan, ukuran perusahaan, dan usia perusahaan sebagai berikut:

Tabel 2.

Definisi Pengukuran Variabel Penelitian

\begin{tabular}{lcccc}
\hline \multicolumn{1}{c}{ Variabel } & Proksi & Indikator & Skala & Sumber \\
\hline $\begin{array}{l}\text { DEPENDEN } \\
\text { Nilai }\end{array}$ & TOBINS & $\frac{(E M V+D E B T)}{(E B V+D E B T)}$ & Rasio & Herawaty, (2008) \\
Perusahaan & 'Q & & & \\
$\begin{array}{l}\text { INDEPENDE } \\
\text { Kepemilikan } \\
\text { Institusional }\end{array}$ & IOWN & $\frac{\text { Total sahan dimiliki institusional }}{\text { Total saham beredar }}$ & Rasio & Herawaty, (2008) \\
Profitabilitas & ROA & $\frac{\text { Laba bersih setelah pajak }}{\text { Total aset }}$ & Rasio & (Noviani et al., \\
& & & & 2019) \\
\hline
\end{tabular}

Bersambung... 
Lanjutan Tabel 2.

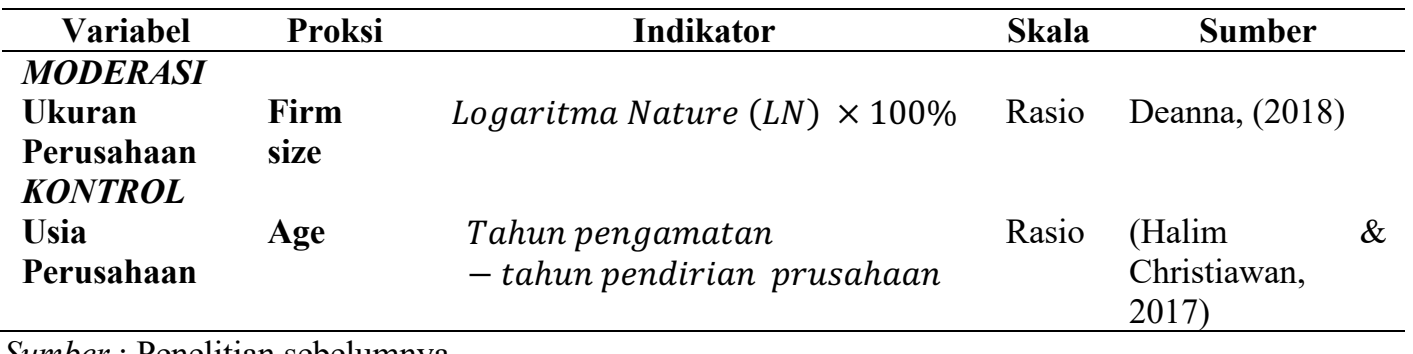

Sumber : Penelitian sebelumnya

Pada penelitian ini variabel yang akan diuji terdiri dari tiga variabel dependen yaitu kepemilikan institusional, komite audit, dan profitabilitas, variabel independen yaitu nilai perusahaan, sedangkan variabel moderasi yaitu ukuran perusahaan, dan variabel kontrolnya yaitu usia perusahaan. Usia perusahaan dalam penelitian ini dijadikan variabel kontrol untuk mengetahui apakah variabel usia perusahaan ini perlu dinetralisir, dikeluarkan, atau dipertahankan tetap dan mampu mengendalikan pengaruh variabel kepemilikan institusional, komite audit, dan profitabilitas terhadap nilai perusahaan.

Teknik analisis data dalam penelitian ini menggunakan regresi linear ganda dengan moderasi. Bentuk persamaan peneliti sebagai berikut:

$Y_{i t}=\propto+\beta_{i t} 1 X_{i t} 1+\beta_{i t} 2 X_{i t} 2+\beta_{i t} 3 X_{i t} 3+\beta_{i t} 4 X_{i t} 1 Z_{i t} 1+\beta_{i t} 5 X_{i t} 2 Z_{i t} 1+$ $\beta_{i t} 6 X_{i t} 3 Z_{i t} 1+e$.

Keterangan:

$Y_{i t}$

$X_{i t} 1$

$X_{i t} 2$

$X_{i t} 3$

$Z_{i t} 1$

$X_{i t} 1 Z_{i t} 1 \quad=$ Interaksi antara variabel kepemilikan institusional dengan ukuran perusahaan

$X_{i t} 2 Z_{i t} 1=$ Interaksi antara variabel komite audit dengan ukuran perusahaan

$X_{i t} 3 Z_{i t} 1=$ Interaksi antara variabel ROA dengan ukuran perusahaan

$\propto \quad=$ kostanta

$\beta \quad=$ koefisien regresi

e $\quad=$ error

$i \quad=$ perusahaan asuransi

$t \quad=$ tahunan

\section{HASIL DAN PEMBAHASAN}

Tabel 3. menunjukan statistik deskriptif dari sampel yang diteliti. Data diolah dari 36 perusahaan yang menjadi sampel. Berdasarkan tabel tersebut dapat diketahui bahwa sebaran data sudah baik karena hampir setiap variabel memiliki standar deviasi lebih kecil dari nilai rata-rata. Namun demikian, untuk variabel Nilai Perusahaan sebaran data kurang baik karena terdapat perbedaan nilai yang jauh antara nilai minimum dan maksimum. 
Tabel 3.

Hasil Statistik Deskriptif

\begin{tabular}{llllll}
\hline Variabel & $\mathrm{N}$ & $\mathrm{Min}$ & $\mathrm{Max}$ & Mean & Stand.Dev \\
\hline Nilai Perusahaan & 36 & 2.130 & 10.555 & 2.130 & 2.386 \\
Kepemilikan Institusional & 36 & 0.099 & 1.000 & 0.652 & 0.042 \\
Komite Audit & 36 & 2 & 4 & 2.944 & 0.333 \\
ROA & 36 & -0.198 & 0.455 & 0.037 & 0.088 \\
Ukuran Perusahaan & 36 & 17.092 & 33.680 & 24.498 & 4.465 \\
Usia Perusahaan & 36 & 35 & 67 & 51.167 & 11.736 \\
\hline
\end{tabular}

Sumber: Data sekunder diolah,2020

Nilai Perusahaan memiliki nilai rata-rata sebesar 2,130 dengan nilai maksimum sebesar 10,555 yang terdapat pada Perusahaan Asuransi Multi Artha Guna Tbk dan nilai minimum 2,130 pada Perusahaan Asuransi Kresna Mitra Tbk serta standar deviasi sebesar 2,386. Hal ini menunjukan bahwa nilai perusahaan yang diteliti cukup tinggi, tercermin dari nilai rata-rata lebih besar dari 1 . Hal ini mengindikasi nilai pasar lebih tinggi dari nilai aset. Sehingga disimpulkan bahwa pasar memberikan penilaian lebih tinggi terhadap perusahan.

Hasil statistik deskriptif pada Tabel 3. menunjukan bahwa Kepemilikan Institusional (KI) memiliki standar deviasi sebesar 0,042 nilai minimum sebesar 0,099 yang dimiliki oleh Perusahan Panininvest Tbk dan nilai maksimum diperoleh dari Perusahaan Asuransi Harta Aman Pratama Tbk. Nilai rata-rata KI sebesar 0,652 menunjukan bahwa sebagian besar saham perusahaan asuransi dimiliki oleh institusi.

Komite audit memiliki nilai maksimum sebesar 4 dan nilai minimum 2 serta standar deviasi sebesar 0,333 dan rata-rata sebesar 2,944 (setara 3) menunjukan perusahaan asuransi memenuhi kriteria minimal komite audit dalam perusahaan yang dikeluarkan POJK Nomor 55/POJK.04/2015 tentang pembentukan dan pedoman pelaksaan kerja komite audit, dimana komite audit sedikitnya terdiri dari tiga orang berasal dari komisaris independen dan pihak luar perusahaan.

ROA mempunyai nilai maksimum 0,455 pada Perusahaan Asuransi Multi Artha Guna Tbk dan nilai minimum -0,198 pada Perusahaan Asuransi Harta Aman Pratama Tbk serta standar deviasi 0,088. ROA pada perusahaan asuransi kurang baik dikarenakan nilai rata-rata yang dihasilkan hanya sebesar 0,037 , lebih rendah dari rata-rata suku bunga bebas risiko.

Ukuran perusahaan yang diukur dengan Ln Total Asset memiliki nilai maksimum sebesar 33,680 pada Perusahaan Lippo Gineral Insurance Tbk dan nilai minimum 17,092 pada Perusahaan Malacca Trust Wuwungan Insurance Tbk serta nilai rata-rata sebesar 24,498 dan nilai standar deviasi sebesar 4,465.

Umur yang diukur dengan lama perusahaan berdiri memiliki nilai maksimum sebesar 67 pada Perusahaan Lippo Gineral Insurance Tbk dan nilai minimum 35 pada Perusahaan Asuransi Bina Dana Arta Tbk serta standar deviasi sebesar 11,736. Dapat dikatakan bahwa perusahan asuransi merupakan perusahaan yang sudah 
mapan, ini dikarenakan nilai rata-rata usia perusahaan yang dihasilkan hanya sebesar 51,167 angka rata-rata ini menyatakan bahwa lama berdirinya perusahaan Asuransi yang menjadi objek penelitian berumur 51 tahun.

Tabel 4.

Hasil Uji Stasioner

\begin{tabular}{lll}
\hline Variabel & Prob. & Keterangan \\
\hline NP & 0,0001 & Stasioner \\
KI & 0,0028 & Stasioner \\
KA & 0,0000 & Stasioner \\
ROA & 0,0000 & Stasioner \\
Ukuran & 0,0001 & Stasioner \\
Usia & 0,0000 & Stasioner \\
KI_Ukuran & 0,0000 & Stasioner \\
KA_Ukuran & 0,0000 & Stasioner \\
ROA_Ukuran & 0,0000 & Stasioner \\
\hline \multicolumn{2}{c}{$*$ Augmented Dickey-Fuller test }
\end{tabular}

Sumber: Data sekunder diolah, 2020

Tabel 4. menunjukkan hasil uji stasioner dengan menggunakan augmented dickey-fuller test. Uji stasioner merupakan tahap awal dalam uji regresi data panel. Uji ini dilakukan untuk mengetahui ada atau tidak panel unit root antara variabel peneliti, yang membuat hubungan antar variabel menjadi valid. Pada penelitian ini digunakan Statistik uji tingkat level dan first differencing menjadi dasar pengujian panel unit root. Variabel dikatakan lolos uji stasioner ketika nilai prob. lebih kecil dari 0,05. Hasil pengujian panel unit root secara lengkap tersaji dalam tabel 4 .

Pada Tabel 4. dapat dilihat bahwa semua nilai prob lebih kecil dari 0,05, maka dapat diambil kesimpulan bahwa semua variabel peneliti lolos uji stasioneritas. Dengan lolosnya uji stasioneritas pada setiap variabel menunjukan bahwa peneliti dapat melanjutkan pengujian ke tahap selanjutnya, yaitu uji pemilihan model.

Pemilihan model regresi yang tepat dilakukan melalui tiga uji yang dilakukan yaitu uji chow, uji hausman, dan uji lagrange multiplier yang hasilnya dapat dilihat sebagai berikut:

Tabel 5.

Uji Chow

\begin{tabular}{lll}
\hline Effect Test & Statistic & Prob. \\
Cross-Section F & 5.307 & 0.001 \\
Cross-Section Chi-Square & 55.314 & 0.000 \\
\hline Sumber: Data sekunder diolah, 2020 & &
\end{tabular}

Sumber: Data sekunder diolah, 2020

Berdasarkan hasil uji chow yang dilakukan untuk memilih model yang cocok antara CEM dan FEM, probabilitas yang dihasilkan dari uji chow sebesar 0,000 kurang dari $\alpha(0,05)$ maka model sementra yang cocok untuk digunakan adalah fixed effect model (FEM), kemudian dilanjutkan uji hausman. 
Tabel 6.

Uji Hausman

\begin{tabular}{lll}
\hline Test Summary & Chi-Sq. Statistic & Prob. \\
Cross-section random & 7.866 & 0.447 \\
\hline
\end{tabular}

Sumber: Data sekunder diolah, 2020

Untuk melengkapi uji diatas, selanjutnya dilakukan uji hausman untuk memilih model yang baik antara FEM dan REM. Hasil uji hausman probabilitas 0,44 lebih besar dari $\alpha(0,05)$ sehingga model sementara yang cocok untuk digunakan adalah random effect model (REM) dan dilanjutkan dengan uji lagrange multiplier.

Tabel 7.

Langrange Multiplier

\begin{tabular}{lll}
\hline & Cross-section & Prob. \\
Breusch-Pagan & 3.741748 & 0.0531 \\
\hline
\end{tabular}

Sumber: Data sekunder diolah, 2020

Langkah terakhir untuk menentukan model REM atau CEM yang tepat untuk diterapkan maka dilakukan uji lagrange multiplier yang menunjukkan nilai probabilitas Breusch-Pagan sebesar 0,053 lebih besar dari $\alpha(0,05)$ sehingga model yang paling tepat digunakan adalah common effect model (CEM).

Hasil dari tiga uji yang telah dilakukan di atas dapat disimpulkan bahwa model terbaik yang dapat digunakan adalah common effect model (CEM). Guna membuktikan kebenaran hipotesis yang dibangun yaitu pengaruh langsung dan pengaruh moderasi antar variabel digunakan regresi data panel berdasarkan model yang tepat untuk setiap hipotesis. Hasil analisis dapat dilihat dalam Tabel 8.

Tabel 8.

Hasil Pengujian Hipotesis

\begin{tabular}{lllll}
\hline \multicolumn{2}{c}{ Variable } & Coefficient & t-Statistic & Prob. \\
\cline { 1 - 2 } Dependen & Independen & & & \\
\hline & KI & 15.759 & 1.937 & 0.063 \\
& KA & -9.700 & -1.027 & 0.313 \\
NP & ROA & 15.538 & 0.172 & 0.865 \\
& Ukuran & -0.656 & -0.576 & 0.569 \\
& Perusahaan & & & \\
& $\begin{array}{l}\text { Usia } \\
\text { Perusahaan }\end{array}$ & -0.024 & -0.744 & 0.463 \\
\hline
\end{tabular}

Bersambung... 
Lanjutan Tabel 8.

\begin{tabular}{|c|c|c|c|c|}
\hline \multicolumn{2}{|c|}{ Variable } & \multirow[t]{2}{*}{ Coefficient } & \multirow[t]{2}{*}{ t-Statistic } & \multirow[t]{2}{*}{ Prob. } \\
\hline Dependen & Independen & & & \\
\hline & $\begin{array}{l}\text { KA_Ukuran } \\
\text { Perusahaan }\end{array}$ & 0.390 & 1.098 & 0.282 \\
\hline & $\begin{array}{l}\text { KI_Ukuran } \\
\text { Perusahaan }\end{array}$ & -0.753 & -2.287 & 0.030 \\
\hline & $\begin{array}{l}\text { ROA_Ukuran } \\
\text { Perusahaan }\end{array}$ & -0.109 & -0.033 & 0.974 \\
\hline $\mathrm{R}^{2}$ & $=$ & 0.428 & & \\
\hline \multicolumn{2}{|l|}{ F-statistic } & & 4.281 & \\
\hline \multicolumn{2}{|c|}{ Prob. (F-statistic) } & & 0.002 & \\
\hline
\end{tabular}

Sumber: Data sekunder diolah, 2020

Berdasarkan hasil yang diperoleh koefisien variabel KA, KI_Ukuran Perusahaan dan ROA_ Ukuran Perusahaan memiliki arah negatif. Sedangkan koefisien variabel KI, ROA, dan KA_Ukuran Perusahaan menunjukkan arah yang positif. Hasil uji t untuk uji pengaruh secara parsial menunjukkan nilai sig. untuk variabel KI, KA, dan ROA, masing-masing sebesar 0,06; 0,313 dan 0,865 dimana nilai ini lebih besar dari 0,05 sehingga hipotesis 1, 2, 3 ditolak atau Kepemilikan Institusional, Komite Audit dan ROA tidak berpengaruh terhadap Nilai Perushaaan.

Hasil pengujian pengaruh KA terhadap NP dimoderasi oleh Ukuran Perusahaan dan pengaruh ROA tehadap NP dimoderasi oleh Ukuran Perusahaan menunjukan nilai sig. sebesar 0,282 dan 0,974 lebih besar dari 0,05 sehingga hipotesis 5 dan 6 ditolak atau variabel Ukuran Perusahaan tidak dapat memoderasi pengaruh antara Komite Audit dan ROA terhadap Nilai Perusahaan. Sedangkan pengaruh KI terhadap NP yang dimoderasi oleh Ukuran Perusahaan menunjukan nilai sig. 0,030 (coefficien negatif) lebih kecil dari 0,05 maka hipotesis 4 diterima atau ukuran perusahaan memperlemah pengaruh antara Kepemilikan institusional terhadap Nilai Perusahaan.

Nilai koefisien dari variabel Usia Perusahaan menunjukan arah negatif. Hasil uji t varibel kontrol Usia Perusahaan menunjukkan nilai sig. 0,463 lebih besar dari 0,05 sehingga hipotesis 7 ditolak atau variabel kontrol Usia Perusahaan tidak berpengaruh terhadap Nilai perusahaan.

Hasil koefisien determinasi $\left(\mathrm{R}^{2}\right)$ memunjukan hasil 0,428 yang berarti bahwa Kepemilikan Institusional, Komite Audit, Profitabilitas, Ukuran Perusahaan dan Umur Perusahaan mampu menjelaskan variabel Nilai Perushaaan sebesar 42,8\%, sedangkan sisanya 57,2\% dijelaskan oleh variabel lain diluar penelitian.

Berdasarkan hasil Uji F diperoleh hasil prob. 0,002 $<\alpha(0,05)$ maka dapat diartikan secara keseluruhan variabel independent KA, KI, ROA, Ukuran Perusahaan, dan Usia Perusahaan mampu mempengaruhi Nilai Perusahaaan. 
Kepemilikan institusional tidak berpengaruh terhadap nilai perusahaan diduga berkaitan dengan statistika deskriptif yang menunjukkan bahwa rata-rata kepemilikan institusi pada industri asuransi cukup tinggi sehingga hal ini mengindikasikan pola data yang cenderung homogen antar perusahaan dalam industri asuransi. Akibat dari homogenitas ini maka data yang ada tidak dapat mendukung hipoetsis yang dirumuskan sebelumnya berkaitan dengan pengaruh kepemilikan insitusi terhadap nilai perusahaan asuransi. Good corporate governance yang diproksi dengan kepemilikan institusional ternyata tidak menunjukkan hasil sesuai hipotesis karena karakteristik khas pada industri asuransi yang memiliki kesamaan dalam porsi kepemilikan insitusi. Dengan demikian penelitian mendatang dapat menggunakan proksi lain untuk mengukur good corporate governance pada industry asuransi.

Hasil penelitian bertolak belakang dengan hipotesis pada penelitian, penelitian ini menunjukkan kepemilikan institusional tidak berpengaruh terhadap nilai perusahaan pada periode 2017-2019. Hal ini menyebabkan kepemillikan institusional tidak dapat mengoptimalkan kontrolnya terhadap manajer sehingga belum mampu menjadi mekanisme dalam meningkatkan nilai perusahaan. Adapun faktor lain bahwa investor tidak mempertimbangkan kepemilikan institusional dalam membeli saham, karena kepemilikan institusional merupakan bagian dari mekanisme GCG dimana perusahaan yang sudah go public wajib melakukan tata kelola yang baik, sehingga dalam membeli saham investor tidak lagi menilai dari kepemilikan institusional yang ada diperusahaan. Hasil penelitian ini sejalan dengan penelitian yang dilakukan oleh oleh Thaharah \& Asyik (2016) dan Meindarto \& Lukiastuti (2016) yang menyatakan GCG yang diproksi dengan kepemilikan institusional tidak berpengaruh terhadap nilai perusahaan.

Komite Audit tidak berpengaruh terhadap nilai perusahaan. Pada periode pengamatan jumlah komite audit tidak terbukti dapat mempengaruhi minat investor untuk membeli saham perusahan tersebut. Hasil tersebut tidak sesuai dengan hipotesis yang telah dibangun peneliti. Komite audit memiliki peran yang penting dalam penyusunan laporan keuangan yang berkualitas. Faktor penyebab tidak berpengaruhnya jumlah dewan komite audit terhadap nilai perusahaan diduga karena investor tidak lagi menilai komite audit dalam membeli saham perusahaan. Sebagaimana yang diatur dalam POJK Nomor 55/POJK.04/2015 bahwa setiap perusahaan wajib minimal memiliki 3 komite audit sehingga investor akan berasumsi dan yakin bahwa setiap perusahaan sudah menjalankan GCG dan memiliki jumlah komite audit sesuai sehingga tidak perlu lagi mempertimbangkan komite audit dalam melakukan investasi atau membeli saham. Hasil penelitian ini sejalan dengan penelitian yang dilakukan oleh oleh Thaharah \& Asyik (2016) dan Meindarto \& Lukiastuti (2016) yang menyatakan GCG yang diproksi dengan komite audit tidak berpengaruh terhadap nilai perusahaan.

Dari hasil uji yang sudah dilakukan menyatakan bahwa GCG yang diproksi dengan kepemilikan institusional dan komite audit tidak berpengaruh terhadap nilai perusahaan. Tidak berpengaruhnya variabel tata kelola perusahaan terhadap nilai perusahaan diduga berkaitan dengan sifat industri asuransi yang highly regulated sehingga focus industry tersebut adalah kepatuhan terhadap peraturan OJK yang bersifat mengikat dan wajib dilakukan. 
Profitabilitas tidak berpengaruh terhadap nilai perusahaan. Hal ini menunjukan bahwa keuntungan yang dihasilkan oleh perusahaan asuransi pada periode pengamatan tidak mempengaruhi investor untuk membeli saham pada perusahaan tersebut. Hal ini bertentangan dengan penelitian Chen \& Chen (2011) jika ditinjau kembali seharusnya profitabilitas akan mempengaruhi nilai perushaaan, hal ini dikarenakan perusahaan dengan tingkat profitabilitas yang tinggi menunjukan kemampuan perusahan mengelola asset yang ada untuk menghasilkan laba sebesar-besarnya. Dengan demikian tingkat pengembalian atas investasi akan semakin tinggi dan hal ini dapat menarik investor untuk menanamkan modalnya, karena tujuan dari investor adalah mencari keuantungan. Namun, pada perusahan asuransi investor tidak mempertimbangkan tingkat keuntungan yang dihasilkan oleh perusahaan karena rata-rata profitabilitas perusahaan asuransi tergolong kecil. Sehingga dalam melakukan investasi atau membeli saham investor mempertimbangkan faktor-fakor lain di luar profitabilitas.

Ukuran perusahaan memperlemah pengaruh kepemilikan institusional terhadap nilai perusahaan. Kepemilikan institusional akan meningkatkan pengawasan perusahaan sehingga mampu mengurangi biaya keagenan di perusahaan. Biaya keagenan yang berkurang akan meningkatkan nilai perusahaan. Namun berdasarkan hasil penelitian ini menunjukan bahwa semakin besar ukuran perusahaan dapat memperkecil pengaruh kepemilikan institusional terhadap nilai perusahaan. Hal ini menyebabkan pengawasan kepemilikan institusional terhadap manajemen kurang baik, sehingga biaya keagenan kurang terkontrol dan dapat menyebabkan kurang terjaminnya kemakmuran pemililk saham. Hal ini dianggap menjadi hal yang kurang baik bagi investor sehingga semakin besar ukuran perusahaan maka akan semakin kecil nilai perusahaan yang dicerminkan oleh harga saham.

Ukuran perusahaan tidak dapat memoderasi pengaruh komite audit terhadap nilai perusahaan. Hasil penelitian menunjukan bahwa Perusahaan dengan ukuran asset yang besar ataupun kecil akan tetap melakukan penerapan komite audit, sebagaimana yang sudah diatur dalam POJK Nomor 55/POJK.04/2015. Dalam melakukan investasi, investor tidak mempertimbangkan jumlah komite audit pada besar atau kecilnya ukuran perusahaan karena setiap perusahaan baik berukuran kecil maupun besar pasti memiliki jumlah komite audit yang sebagaimana sudah diatur. Berdasarkan alasan tersebut maka ukuran perusahan tidak dapat dijadikan sebagai variabel moderasi dalam pengaruhnya antara Komite Audit terhadap Nilai Perusahaan.

Ukuran perusahaan tidak dapat memoderasi pengaruh profitabilitas terhadap nilai perusahaan. Hasil penelitian menunjukan bahwa ukuran perusahaan bukan menjadi indikator penentu investor dalam melakukan investasi, karena tidak ada jaminan perusahaan dengan ukuran lebih besar mempunyai kinerja yang lebih baik dibandingkan ukuran perusahaan yang lebih kecil. Kinerja keuangan perusahaanlah menjadi faktor penilaian investor dalam melakukan investasi. Hal inilah yang diduga kuat menjadi penyebab tidak dapatnya variabel ukuran perusahaan menjadi pemoderasi antara pengaruh Profitabilitas terhadap nilai perusahaan. Adapun faktor lain yang diduga adalah karena tidak adanya pengaruh antara profitabilitas terhadap nilai perusahaan pada objek yang diteliti. 
Usia Perusahaan tidak berpengaruh terhadap nilai perusahaan. Usia perusahaan yang semakin lama tidak menjamin perusahaan dapat menghasilkan profit lebih daripada perusahaan yang baru berdiri, sebab pada saat tertentu pendapatan perusahaan yang telah lama berdiri akan mengalami penurunan yang disebabkan oleh munculnya perusahaan baru atau perusahaan yang sudah lama masuk ke dalam tahapan decline sehingga adanya penurunan performa. Hal ini dapat menjadi sinyal buruk bagi investor dalam menilai perusahaan, karena investor tidak memperhitungakan umur perusahaan. Namun terdapat faktor-faktor lain yang diduga dapat mempengaruhi keputusan investor dalam melakukan investasi atau membeli saham.

\section{SIMPULAN}

Berdasarkan hasil penelitian GCG, profitabilitas terhadap nilai perusahaan asuransi dengan efek moderasi ukuran perusahaan penulis menyimpulkan: 1) Good Corporate Goverment tidak berpengaruh terhadap nilai perusahaan asuransi. 2) Profitabilitas tidak berpengaruh terhadap nilai perusahaan. 3) Ukuran perusahaan memperlemah pengaruh kepemilikan institusional terhadap nilai perusahaan. 4) Ukuran perusahaan tidak dapat memoderasi pengaruh profitabilitas terhadap nilai perusahaan. 5) Usia perusahaan sebagai variabel kontrol juga tidak berpengaruh terhadap nilai perusahaan.

Penelitian ini memberikan bukti empiris yang diharapkan dapat berkontribusi secara teoritis terkait efek moderasi ukuran perusahaan terhadap pengaruh antara GCG, Profitabilitas terhadap Nilai Perusahaan. Selain itu penelitian ini diharapkan dapat bermanfaat bagi perusahaan sebagai bahan evaluasi, dan memberikan informasi-informasi penting bagi para investor sebagai bahan pertimbangan. Proksi-proksi yang dipilih dalam penelitian ini tidak berpengaruh sehingga untuk penelitian selanjutnya untuk menggunakan proksi lain diluar penelitian ini.

\section{REFERENSI}

Amanda, E. Z., \& Rambu Atahau, A. D. (2020). Prediksi Kebangkrutan PT Asuransi Jiwasraya dan PT Prudential Life Insurance: Aplikasi Metode Altman Z-Score. Jurnal Riset Akuntansi Politala, 3(1), 17-24. https://doi.org/10.34128/jra.v3i1.42

Ang, J. S., Cole, R. A., \& Lin, J. W. (2000). Agency Costs and Ownership Structure. The Journal of Finance, 1(1), 81-106.

Badruddien, Y., Gustyana, T. T., \& Dewi, A. S. (2017). THE INFLUENCE OF GOOD CORPORATE GOVERNANCE, LEVERAGE AND FIRM SIZE TO FIRM VALUE ( EMPIRICAL STUDY ON THE CONSUMER GOODS INDUSTRY SECTOR IN INDONESIA STOCK EXCHANGE PERIOD 2012-2015). E-Proceeding of Management, 4(3), 2236-2243.

bps. (2021). No Title. 
Chen, L.-J., \& Chen, S.-Y. (2011). The influence of profitability on firm value with capital structure as the mediator and firm size and industry as moderators. Investment Management and Financial Innovations, 8(3), 121-129.

Daryaei, A. A., \& Fattahi, Y. (2020). The asymmetric impact of institutional ownership on firm performance: panel smooth transition regression model. The International Journal of Business In Society, 1-13. https://doi.org/10.1108/CG-06-2020-0254

Deanna, J. N. (2018). Determinan Efisiensi Operasional Perbankan Indonesia (Studi Empiris pada Perbankan Umum Konvensional di Indonesia Tahun 2011-2016). Jurnal Muara Ilmu Ekonomi Dan Bisnis, 2(1), 218-225. https://doi.org/10.24912/jmieb.v2i1.1554

Ellili, N. O. D. (2011). Ownership Structure, Financial Policy and Performance of the Firm: US Evidence. International Journal of Business and Management, 6(10), 80-93. https://doi.org/10.5539/ijbm.v6n10p80

Fayezi, S., Loughlin, A. O., \& Zutshi, A. (2012). Agency theory and supply chain management: a structured literature review. Supply Chain Management: An International Journal, 17(5), 556-570. https://doi.org/10.1108/13598541211258618

Firmansyah, Z. (2017). Ukuran Perusahaan, Profitabilitas, Volatilitas Pendapatan, dan Resiko Bisnis Terhadap Nilai Perusahaan dengan Kebijakan Hutang Sebagai Variabel Moderating Pada Saham JII (Jakarta Islamic Index) Di Bursa Efek Indonesia. Asian Journal of Innovation and Entrepreneurship, 02(01), $13-24$.

Hadya, R., \& Fernandes, J. (2020). Tingkat Keuntungan dan Usia Perusahaan Terhadap Leverage: Estimasi Model Data Panel Di Indonesia. Jurnal Apresiasi Ekonomi, 8(2), 292-299. https://doi.org/10.31846/jae.v8i2.315

Halim, H. A., \& Christiawan, Y. J. (2017). PENGARUH PENERAPAN CORPORATE GOVERNANCE TERHADAP NILAI PERUSAHAAN DENGAN UKURAN PERUSAHAAN DAN UMUR PERUSAHAAN SEBAGAI VARIABEL KONTROL. Business Accounting Review, 5(2), 181192.

Hansen, V., \& Huniarti. (2014). Perngaruh Family Control, Size, Sales Growth, Dan Leverage Terhadap Profitabilitas dan Nilai Perusahaan Pada Sektor Perdagangan, Jasa, dan Investasi. Business Accounting Review, 2(1), 121-130. https://doi.org/10.1017/CBO9781107415324.004

Herawaty, V. (2008). Peran Praktek Corporate Governance Sebagai Moderating Variable dari Pengaruh Earnings Management Terhadap Nilai Perusahaan. 
Jurnal Akutansi Dan Keuangan, 10(02), 97-108. https://doi.org/10.1007/BF00897945

Kompas. (2020). No Title.

Le Thi Kim, N., \& Le Thanh, H. (2020). Determinants of financial performance of listed firms manufacturing food products in Vietnam: regression analysis and Blinder-Oaxaca decomposition analysis. Journal of Economics and Development, 1-17. https://doi.org/10.1108/jed-09-2020-0130

Meindarto, A., \& Lukiastuti, F. (2016). Pengaruh Corporate Governance Terhadap Nilai Perusahaan Pada Perusahaan Perbankan Yang Terdaftar Di BEI Tahun 2011-2014. STIE Bank BPD Jateng Semarang. Telaah Bisnis, 17(2), 145-168.

Muchtar, S., \& Darari, E. (2013). Pengaruh Corporate Governance Terhadap Kinerja Perusahaan yang Terdaftar Di Bursa Efek Indonesia. Jurnal Manajemen Dan Pemasaran Jasa, 6, 109-132.

Muryati, N. N. T. S., \& Suardikha, I. M. S. (2014). Pengaruh Corporate Governance Pada Nilai Perusahaan. E-Jurnal Akuntansi, 9(2), 411-429.

Noviani, A. V., Atahau, A. D. R., \& Robiyanto, R. (2019). Struktur modal, profitabilitas, dan nilai perusahaan: Efek moderasi Good Corporate Governance. Jurnal Ekonomi Dan Bisnis, 22(2), 391-415. https://doi.org/10.24914/jeb.v22i2.2601

OJK RI. (2015). Peraturan Otoritas Jasa Keuangan Nomor 55 /Pojk.04/2015 Tentang Pembentukan Dan Pedoman Pelaksanaan Kerja Komite Audit. Ojk.Go.Id, 1-14. Retrieved from http://www.ojk.go.id/id/kanal/iknb/regulasi/lembaga-keuanganmikro/peraturan-ojk/Documents/SAL-POJK PERIZINAN FINAL F.pdf

OJK RI. (2016). Peraturan Otoritas Jasa Keuangan Nomor 73/POJK.05/2016 Tentang Tata Kelola Perusahaan yang Baik bagi Perusahaan Perasuransian. Ojk.Go.Id, 1-53.

Oktariyani, Nugraha, I. N., Sofiyah, S., Negara, I. K., \& Mandra, I. G. (2017). Pengaruh Good Corporate Governance Terhadap Nilai Perusahaan Dengan Profitabilitas Sebagai Variabel Intervening. Jurnal Distribusi, 5(2), 45-58. https://doi.org/10.32477/jkb.v25i1.228

Ozdemir, O. (2020). Board Diversity and Firm Performance in The U.S. Tourism Sector: The Effect of Institutional Ownership. International Journal of Hospitality Management, 91, $1-11$. https://doi.org/10.1016/j.ijhm.2020.102693 
Pacini, C., Hillison, W., \& Marlett, D. (2008). Board Size and Firm Perfomance in The Property-Liability Insurance Industry. Research in Finance, 24, 249-285.

Perdana, R. S., \& Rahaja. (2014). Analisis Pengaruh Corporate Governance Terhadap Nilai Perusahaan. Diponegoro Journal Of Accounting, 3(3), 1-13.

Permata, A. D., Nurlaela, S., \& Wahyuningsih, E. M. (2018). Pengaruh Size, Age, Profitability, Leverage dan Sales Growth Terhadap Tax Avoidance. Jurnal Akuntansi Dan Pajak, 19(1), 10-20. https://doi.org/10.29040/jap.v19i1.171

Pramana, I. G. N. A. D., \& Mustanda, I. K. (2016). PENGARUH PROFITABILITAS DAN SIZE TERHADAP NILAI PERUSAHAAN DENGAN CSR SEBAGAI VARIABEL PEMODERASI. E-Jurnal Manajemen Unud, 5(1), 561-594.

Purbopangestu, H. W., \& Subowo. (2014). Pengaruh Good Corporate Governance Terhadap Nilai Perusahaan Dengan Corporate Social Responsibility Sebagai Variabel Intervening. Accounting Analysis Journal, 3(3), 321-333. https://doi.org/10.15294/aaj.v3i3.4202

Rahardjo, B. T., \& Murdani, R. (2016). Pengaruh Kinerja Keuangan Dan Pengungkapan Corporate Social Responsibility Terhadap Nilai Perusahaan (Studi Kasus Pada Perusahaan Bumn Yang Terdaftar Di Bei Tahun 20102014). Jurnal Akuntansi Dan Bisnis Krisnadwipayana, 3(01), 1-9. https://doi.org/10.35137/jabk.v3i01.54

Saputra, A., Utami, I., \& Kristianti, I. (2018). Akuntabilitas dan Transparansi Pelaporan Keuangan Pemerintah Daerah Serta Potensi Whistleblowing Atas Penyalahgunaan Dana. Jurnal Ilmiah Wahana Akuntansi, 13(1), 13-28. https://doi.org/10.21009/wahana.13.012

Sembiring, H. (2012). Analisis Pengaruh Karakteristik Perusahaan Terhadap Kelengkapan Pengungkapan dalam Laporan Tahunan Perusahaan Manufaktur yang Terdaftar Di Bursa Efek Indonesia. Jurnal Mediasi, 4(1), 68-77.

Shu, P.-G., \& Chiang, S.-J. (2014). Firm Size, Timing, and Earnings Management of Seasoned Equity Offerings. International Review of Economics and Finance, 29, 177-194. https://doi.org/10.1016/j.iref.2013.05.011

Siallagan, H., \& Machfoedz, M. (2006). Mekanisme Corporate Governance, Kualitas Laba dan Nilai Perusahaan. Simposium Nasional Akuntansi 9 Padang, (61), 23-26.

Soedaryono, B., \& Riduifana, D. (2013). Pengaruh Good Corporate Governance Terhadap Nilai Perusahaan Melalui Corporate Social Responsibility. Media Riset Akuntansi, Auditing \& Informasi, 13(1), 1-35. 
Subramaniam, V., \& Wasiuzzaman, S. (2019). Geographical diversification, firm size and profitability in Malaysia: A quantile regression approach. Heliyon, 5, 1-12. https://doi.org/10.1016/j.heliyon.2019.e02664

Suhadak, S., Kurniaty, K., Handayani, S. R., \& Rahayu, S. M. (2019). Stock Return and Financial Performance as Moderation Variable In Influence of Good Corporate Governance Towards Corporate Value. Asian Journal of Accounting Research, 4(1), 18-34. https://doi.org/10.1108/ajar-07-2018-0021

Thaharah, N., \& Asyik, N. F. (2016). Pengaruh Mekanisme Corporate Governance Dan Kinerja Keuangan Terhadap Nilai Perusahaan. Jurnal Ilmu Dan Riset Akuntansi, 5(2).

Wahyudin, A., \& Solikhah, B. (2017). Corporate Governance Implementation Rating In Indonesia and Its Effects On Financial Performance. Emerald Publishing Limited, 17(2), 250-265. https://doi.org/10.1108/CG-02-20160034

Wardoyo, \& Veronica, T. M. (2013). pengaruh good corporate governance, CSR dan Kinerja keuangan terhadap nilai perusahaan. Jurnal Dinamika Manajemen, 4(2), 132-149. Retrieved from http://journal.unnes.ac.id/nju/index.php/jdm 